\title{
A mathematical model of an integrated haemodialysis and renal transplantation programme
}

\author{
ROBERT R. WEST, DAVID L. CROSBY, AND J. HENRY JONES \\ Department of Social and Occupational Medicine, Welsh National School of Medicine, and the \\ University Hospital of Wales, Cardiff
}

\section{SUMmaRY}

A mathematical model of an integrated renal dialysis and transplantation programme is described. The three treatment areas-hospital dialysis, home dialysis, and transplantation-are represented in the model by three states and those states are subdivided into one and two substates respectively. Interstate transitions occur at either constant average rate or with constant average probability, depending on the relevant principal constraints. In estimating future numbers in the programme, interstate transition probabilities (or rates) may be adjusted for possible changes, such as an improvement in graft survival. Projection based on data of the early years of the Cardiff unit are compared with developments in later years. The model may be used for the calculation of future numbers in other centres or nationally by substituting the appropriate interstate transition probabilities or rates.

\section{INTRODUCTION}

Ideally, centres providing a service for the treatment of chronic renal failure should develop facilities for hospital dialysis, home dialysis, and renal transplantation. These three forms of treatment are interdependent, and management should be closely integrated As the number of patients treated increases, the number of patients being transferred from one form of treatment to another will also increase, and problems of management and logistics become progressively more difficult. Moreover, future planning requires some means of predicting what facilities will be required and how best to utilize available resources. With this in mind we have developed a mathematical model to assist in the analysis of future trends.

The Cardiff unit provides an integrated hospital dialysis/home dialysis/renal transplant service for a population of about two million people (Branch et al., 1970). The unit opened in April 1968 and during the first five years 198 patients received treatment in the hospital dialysis unit. Seventyseven patients have been on home dialysis, 123 have received a renal transplant, and 35 have had both home dialysis and renal transplantation. Three patients had a renal transplant without prior treatment in the hospital dialysis unit.

The current policy of the unit is to accept all patients under the age of 55 who are not suffering from some other incurable disease, provided they are prepared either to accept a cadaver kidney transplant or to undertake home dialysis training. The capacity of the hospital dialysis unit is for $\mathbf{3 0}$ patients, but the ceiling has been set at 24 regular patients to allow some reserve facilities to deal with failed transplants and temporary readmission from home dialysis.

\section{THE MODEL}

In its simplest form a mathematical model representing the treatment of chronic renal failure is a four-state system, presented diagrammatically in Figure 1. $\mathrm{U}$ represents patients undergoing haemodialysis in the hospital unit, $\mathbf{H}$ home dialysis patients, $T$ patients with transplants and not dependent on dialysis, and $\mathbf{D}$ represents death. Transitions between these states are indicated by arrows. Transitions between $U$ and $T$ and between $\mathrm{U}$ and $\mathrm{H}$ are reversible, but the others are irreversible. A patient undergoing transplantation is represented mathematically by a reduction of the number in state $U$ (the number of patients on dialysis in the hospital unit) and an increase of the number in state $T$ by 1 .

\section{Calculation of Parameters for the Model}

Data for five years ending 30 June 1973 have been used to assess the parameters describing transitions between states in the model. Time units of one month were chosen, and at the end of each 


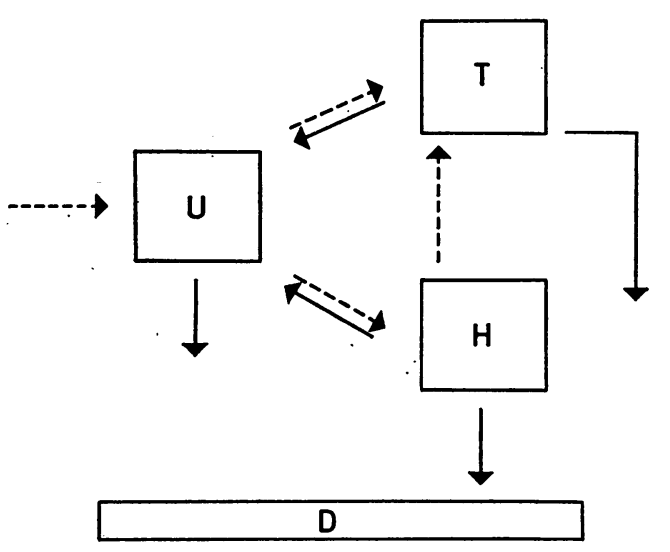

FIG. 1. Four-state model: $U$ represents the dialysis unit, $T$ transplants, $H$ home dialysis, and $D$ death. Transitions with constant average rate, $-\longrightarrow \rightarrow$; transitions with constant average probability

month each patient was assigned to one (and only one) of the four states. Thus, in December 1968 there were 17 in state $U, 13$ in T, 4 in $H$, and 14 in D. In each month a certain number of patients transfer from one mode of treatment to another. The factors that determine the number of transfers are of two types; in one, the number is governed solely by the number in the 'mother' state whereas in the other the number depends on other factors. For example, the numbers of patients transplanted from the hospital unit $(\mathrm{U})$ or from home $(\mathrm{H})$ are dependent on the availability of cadaver kidneys and not on the number of patients awaiting transplants (except when the number is very small). Likewise, the number of patients transferred to home dialysis is dependent on the home training and home conversion rates. Such interstate transfers are shown in Fig. 1 with dashed arrows. Average transplantation and home transfer rates were calculated.

The other transitions, shown as full arrows in Fig. 1, are dependent on the number of patients in the 'mother' state. For these interstate transfers mean transition probabilities were calculated. Thus, in December 1968 one of the 17 patients in the hospital unit died, so the probability of transition $\mathrm{U}$ to $\mathrm{D}$ for that month was therefore approximately $1 / 17$ and the average probability of transition $U$ to $D$ in 1967 and 1968 was 19/412. The average transition rates and average transition probabilities so obtained may then be used to predict the numbers in each state month by month from given starting data. The validity of the predictions may be checked by comparison with the numbers that actually occurred.
Analysis of the data showed that admission rates and interstate transition rates and probabilities have changed during the five years that the dialysis/transplantation programme has been in operation. It was also apparent that the probabilities (or rates) of several interstate transitions depended on the time spent in the 'mother' state. For example, the probability of transition U-D decreases with time spent in the dialysis unit, while the rate of transition $\mathrm{U}-\mathrm{H}$ is zero during the initial months but rises to a peak at four to eight months.

\section{Transitions from Hospital Dialysis Unit}

The outcome in patients treated by hospital dialysis is shown in Table $I$ and Fig. 2. In this context the term 'survival' denotes 'survival' in state $U$ (the hospital dialysis unit) with regard to possible transfers to home dialysis, renal transplantation, and death: it is not the true survival of patients. The six-month and 12-month 'survival' rates are $37 \%$ and $11 \%$ respectively. Of the 198 admissions observed for one month, $23(12 \%)$ were transplanted, $4(2 \%)$ died during the first montho and none was transferred to home dialysis (Table I). After 24 months the number transplanted approaches approximately $50 \%$ of the number admitted to the unit, while the number transferred

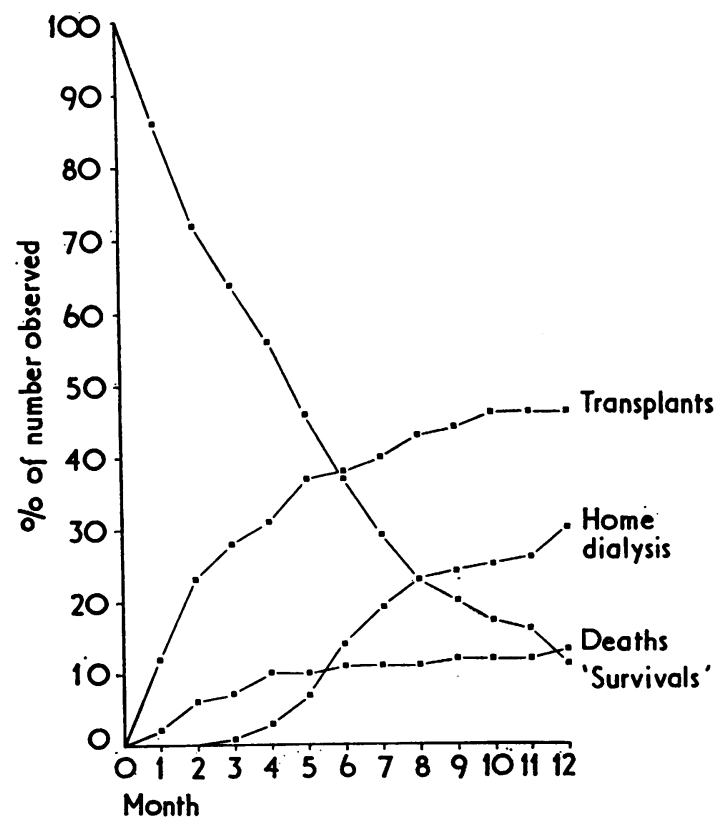

FIG. 2. 'Survival' in hospital dialysis unit, showing transitions from the dialysis unit to states of transplant, home dialysis, and death (see text for use of 'survival'). 
TABLE I

'SURVIVAL' IN HOSPITAL DIALYSIS UNIT-(FIRST ADMISSIONS)*

\begin{tabular}{|c|c|c|c|c|c|c|c|c|c|c|c|c|c|c|c|c|}
\hline & & & \multicolumn{14}{|c|}{ Month } \\
\hline & & & 1 & 2 & 3 & 4 & 5 & 6 & 7 & 8 & 9 & 10 & 11 & 12 & 18 & 24 \\
\hline No. observed & . & .. & 198 & 194 & 189 & 185 & 182 & 180 & 178 & 178 & 175 & 174 & 173 & 166 & 153 & 139 \\
\hline $\begin{array}{l}\text { No. transplanted } \\
\% \text { of number observed }\end{array}$ & 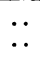 & $\cdots$ & $\begin{array}{l}23 \\
12\end{array}$ & $\begin{array}{l}44 \\
23\end{array}$ & $\begin{array}{l}53 \\
28\end{array}$ & $\begin{array}{l}58 \\
31\end{array}$ & $\begin{array}{l}67 \\
37\end{array}$ & $\begin{array}{l}68 \\
38\end{array}$ & $\begin{array}{l}72 \\
40\end{array}$ & $\begin{array}{l}76 \\
43\end{array}$ & $\begin{array}{l}77 \\
44\end{array}$ & $\begin{array}{l}80 \\
46\end{array}$ & $\begin{array}{l}79 \\
46\end{array}$ & $\begin{array}{l}77 \\
46\end{array}$ & $\begin{array}{l}76 \\
50\end{array}$ & $\begin{array}{l}69 \\
50\end{array}$ \\
\hline $\begin{array}{l}\text { No. on home dialysis } \\
\% \text { of number observed }\end{array}$ & $\begin{array}{l}\cdots \\
\cdots\end{array}$ & $\begin{array}{l}\cdots \\
\cdots\end{array}$ & $\begin{array}{l}\mathbf{0} \\
\mathbf{0}\end{array}$ & $\begin{array}{l}\mathbf{0} \\
\mathbf{0}\end{array}$ & 1 & $\mathbf{5}$ & $\begin{array}{r}13 \\
7\end{array}$ & $\begin{array}{l}26 \\
14\end{array}$ & $\begin{array}{l}34 \\
19\end{array}$ & $\begin{array}{l}41 \\
23\end{array}$ & $\begin{array}{l}42 \\
24\end{array}$ & $\begin{array}{l}44 \\
25\end{array}$ & $\begin{array}{l}45 \\
26\end{array}$ & $\begin{array}{l}49 \\
30\end{array}$ & $\begin{array}{l}47 \\
31\end{array}$ & $\begin{array}{l}46 \\
33\end{array}$ \\
\hline $\begin{array}{l}\text { No. dead } \ldots \\
\% \text { of number observed }\end{array}$ & $\ddot{m}$ & 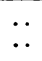 & $\begin{array}{l}4 \\
2\end{array}$ & 11 & $\begin{array}{r}14 \\
7\end{array}$ & $\begin{array}{l}19 \\
10\end{array}$ & $\begin{array}{l}19 \\
10\end{array}$ & $\begin{array}{l}19 \\
11\end{array}$ & $\begin{array}{l}20 \\
11\end{array}$ & $\begin{array}{l}20 \\
11\end{array}$ & $\begin{array}{l}21 \\
12\end{array}$ & $\begin{array}{l}21 \\
12\end{array}$ & $\begin{array}{l}21 \\
12\end{array}$ & $\begin{array}{l}21 \\
13\end{array}$ & $\begin{array}{l}22 \\
14\end{array}$ & $\begin{array}{l}21 \\
15\end{array}$ \\
\hline $\begin{array}{l}\text { 'Survived } * \text { of number observed } \\
\% \text { of num }\end{array}$ & $\ddot{x}$ & $\begin{array}{l}\cdots \\
\cdots\end{array}$ & $\begin{array}{r}171 \\
86\end{array}$ & $\begin{array}{r}139 \\
72\end{array}$ & $\begin{array}{r}121 \\
64\end{array}$ & $\begin{array}{r}103 \\
56\end{array}$ & $\begin{array}{l}83 \\
46\end{array}$ & $\begin{array}{l}67 \\
37\end{array}$ & $\begin{array}{l}52 \\
29\end{array}$ & $\begin{array}{l}41 \\
23\end{array}$ & $\begin{array}{l}35 \\
20\end{array}$ & $\begin{array}{l}29 \\
17\end{array}$ & $\begin{array}{l}28 \\
16\end{array}$ & $\begin{array}{l}19 \\
11\end{array}$ & $\begin{array}{l}8 \\
5\end{array}$ & $\begin{array}{l}3 \\
2\end{array}$ \\
\hline
\end{tabular}

*See text for use of 'survival'

to home dialysis approaches $30 \%$, and the number who died approximately $20 \%$. Figure 2 shows that the number of patients who are transplanted increases relatively smoothly with time, but the death rate decreases markedly after about four months. The home transfer rate, on the other hand, is zero in the initial months and high from about the fourth to eighth months, because it takes time to train patients for home dialysis. Data for readmissions following failure of renal transplants indicate a similar 'survival' rate in the dialysis unit, but the balance between rate of transfer to home dialysis and to retransplantation in the early months is reversed. This is to be expected because patients who were on home dialysis prior to transplantation return home soon after a graft failure as they are already trained.

\section{SuRvival of Renal Transplants}

The 'survival' rates for patients with a functioning kidney graft are shown in Table II and Fig. 3. Again, 'survival' does not mean survival of a patient but 'survival' in the state of transplantation.
The curve representing return to hospital dialysis shows a marked change of slope at about three months (Fig. 3). During the initial months following transplantation graft failures are common (approximately $10 \%$ per month) but after the fourth month the rate of failure is low.

\section{Seven-STAte Model}

Because transfer rates from one state to another are to a certain extent dependent on the time spent in the 'mother' state a larger model was prepared in which there are three substates representing the hospital dialysis unit and two representing transplantation (Fig. 4). In this model an admission (or readmission) goes to state $A$, from which there may be a reversible transition to $\mathrm{T}$, or a non-reversible transition to $H$ or to $D$. However, if a subject experiences no transition out of state $A$ after four months he is considered as a transfer to state $B$, from which he may experience a non-reversible transition to states $T, H$ or $D$. The third state in the hospital dialysis unit $(C)$ is for patients established on home dialysis who return temporarily to hospital

TABLE II

'SURVIVAL' OF RENAL TRANSPLANTS*

\begin{tabular}{|c|c|c|c|c|c|c|c|c|c|c|c|c|c|c|c|c|c|c|}
\hline & \multicolumn{18}{|c|}{ Month } \\
\hline & 1 & 2 & 3 & 4 & 5 & 6 & 7 & 8 & 9 & 10 & 11 & 12 & 18 & 24 & 30 & 36 & 42 & 48 \\
\hline No. observed & 135 & 134 & 131 & 129 & 127 & 125 & 125 & 122 & 120 & 115 & 110 & 104 & 92 & 80 & 66 & 57 & 49 & 34 \\
\hline \multirow{2}{*}{$\begin{array}{l}\text { No. died } \\
\% \text { of number } \\
\text { observed } \quad . .\end{array}$} & 5 & 12 & 16 & 17 & 19 & 22 & 23 & 24 & 23 & 22 & 22 & 24 & 25 & 24 & 19 & 18 & 18 & 14 \\
\hline & 4 & 9 & 12 & 13 & 15 & 18 & 18 & 20 & 19 & 19 & 20 & 23 & 27 & 30 & 29 & 30 & 37 & 41 \\
\hline \multirow{2}{*}{$\begin{array}{l}\text { No. returned to } \\
\text { dialysis } \\
\% \text { of number } \\
\text { observed } \quad .\end{array}$} & 12 & 26 & 40 & 42 & 41 & 42 & 43 & 41 & 41 & 39 & 38 & 36 & 32 & 31 & 26 & 22 & 17 & 13 \\
\hline & 9 & 19 & 30 & 33 & 32 & 34 & 34 & 34 & 34 & 34 & 35 & 35 & 35 & 39 & 39 & 39 & 35 & 38 \\
\hline \multirow{2}{*}{$\begin{array}{l}\text { 'Survived' } . . \\
\% \text { of number } \\
\text { observed } \quad . .\end{array}$} & 118 & 96 & 75 & 70 & 67 & 61 & 59 & 57 & 56 & 54 & 50 & 44 & 35 & 25 & 21 & 17 & 14 & 7 \\
\hline & 88 & 72 & 58 & 54 & 53 & 49 & 47 & 47 & 47 & 47 & 45 & 42 & 38 & 31 & 32 & 30 & 29 & 21 \\
\hline
\end{tabular}




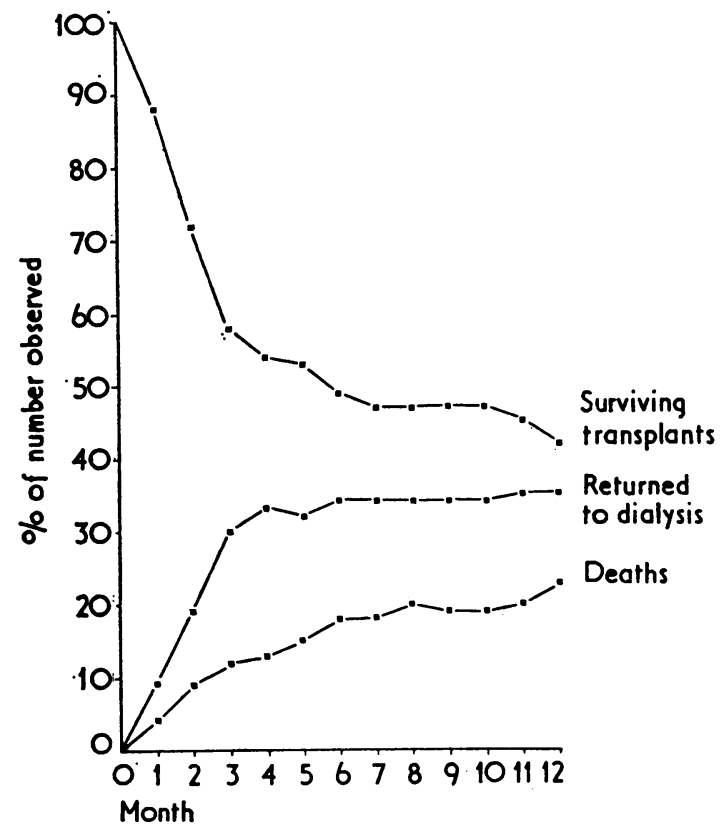

Fig. 3. 'Survival' of renal transplants showing transitions from that state to death and returns to dialysis (see text for use of 'survival').

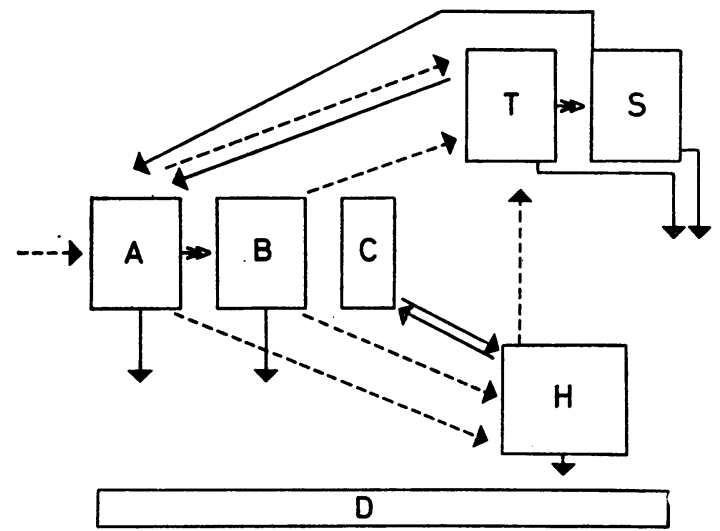

Fig. 4. Seven-state model. A represents the first four months in the dialysis unit, B the dialysis unit after four months, $C$ temporary readmission to the dialysis unit from home, $H$ home dialysis, $T$ the first four months of transplantation, $S$ transplantation after four months, and $D$ death. Transitions with constant average rate $-\longrightarrow \rightarrow$ transitions with constant average probability $\longrightarrow$; transitions that occur after four months $\rightarrow$.

for a few dialyses. For simplicity, possible transition to death from this substate has not been separated from the possible transition from the home dialysis state: all deaths of established home dialysis patients, even if actually occurring in hospital (state $\mathrm{C})$, are ascribed to the home dialysis state $(\mathrm{H})$.
As outlined above, the rate of transfer from the hospital dialysis unit to home dialysis is dependent on the time a patient has been in the hospital unit. Thus the transition rates from $A$ to $H$ and from $B$ to $\mathbf{H}$ differ. Similarly, the transition probability from $A$ to $D$ is not the same as from $B$ to $D$. The transplantation state is also considered as two substates, $\mathbf{T}$ and $\mathbf{S}$. Transplants are placed initially in state $\mathbf{T}$ and those that survive four months move on to state $\mathbf{S}$. This is the model that has been used for predicting the number of patients receiving the three forms of treatment in the near future.

\section{VALIDATION}

In practice the seven-state model is not sensitive to choice of the month that demarcates the pairs of substates (A and $B$, and $T$ and $S$ ) over the range two to six months. Table III gives the interstate transition rates or transition probabilities for 24-month periods beginning in July 1968. Home dialysis was not available before October 1968 but thereafter the number of transfers to home dialysis increased. Survival rates have improved considerably with time (lower probabilities of transition to state $\mathrm{D})$, rates of transfer to home dialysis and to transplantation have increased, and as the unit has filled the rate of admission has decreased.

TABLE III

INTERSTATE TRANSITIONS: MEAN PROBABILITIES OR RATES OF TRANSITIONS FROM ONE STATE TO ANOTHER (PER MONTH)

(a) July 1968 to June 1970 (admission rate 3.4 per month)

\begin{tabular}{|c|c|c|c|c|}
\hline \multirow{2}{*}{$\begin{array}{c}\text { Transition } \\
\text { from } \\
\text { State }\end{array}$} & \multicolumn{2}{|c|}{$\begin{array}{l}\text { Probability per Patient } \\
\text { of Transition to State }\end{array}$} & \multicolumn{2}{|c|}{$\begin{array}{l}\text { Rate of Transition } \\
\text { (patients) to State }\end{array}$} \\
\hline & $\mathbf{A}$ & D & $\mathbf{T}$ & $\mathbf{H}$ \\
\hline $\begin{array}{cc}\mathbf{A} & \cdots \\
\mathbf{B} & \cdots \\
\mathbf{T} & \cdots \\
{ }^{\mathbf{S}} & \cdots\end{array}$ & $\begin{array}{l}\bar{Z} \\
0 . \overline{105} \\
0.008\end{array}$ & $\begin{array}{l}0.068 \\
0.025 \\
0.040 \\
0.023 \\
0.005\end{array}$ & $\begin{array}{l}0.83 \\
0.83 \\
\overline{0.17}\end{array}$ & $\begin{array}{c}0.13 \\
0.92 \\
= \\
=\end{array}$ \\
\hline
\end{tabular}

*Of 200 patient months in $\mathrm{H}, 5$ were in hospital unit (state C).

(b) July 1969 to June 1971 (admission rate 2.7 per month)

\begin{tabular}{|c|c|c|c|c|}
\hline \multirow{2}{*}{$\begin{array}{c}\text { Transition } \\
\text { from } \\
\text { State }\end{array}$} & \multicolumn{2}{|c|}{$\begin{array}{l}\text { Probability per Patient } \\
\text { of Transition to State }\end{array}$} & \multicolumn{2}{|c|}{$\begin{array}{l}\text { Rate of Transition } \\
\text { (patients) to State }\end{array}$} \\
\hline & $\mathbf{A}$ & D & $\mathbf{T}$ & $\mathbf{H}$ \\
\hline $\begin{array}{cc}\mathbf{A} & \cdots \\
\mathbf{B} & \cdots \\
\mathbf{\mathbf { T }} & \cdots \\
\mathbf{*} & \cdots\end{array}$ & $\begin{array}{l}\overline{-} \\
0 \cdot \overline{148} \\
0.009 \\
-\end{array}$ & $\begin{array}{l}0.050 \\
0.019 \\
0.046 \\
0.012 \\
0.009\end{array}$ & $\begin{array}{l}0.71 \\
0.83 \\
= \\
0.38\end{array}$ & $\begin{array}{l}0.17 \\
1.17 \\
= \\
=\end{array}$ \\
\hline
\end{tabular}

*Of 446 patient months in H, 18 were in hospital unit (state C). continued on next page 
continued from previous page

(c) July 1970 to June 1972 (admission rate 2.3 per month)

\begin{tabular}{|c|c|c|c|c|}
\hline \multirow{2}{*}{$\begin{array}{l}\text { Transition } \\
\text { from } \\
\text { State }\end{array}$} & \multicolumn{2}{|c|}{$\begin{array}{l}\text { Probability per Patient } \\
\text { of Transition to State }\end{array}$} & \multicolumn{2}{|c|}{$\begin{array}{l}\text { Rate of Transition } \\
\text { (patients) to State }\end{array}$} \\
\hline & $\mathbf{A}$ & D & $\mathbf{T}$ & $\mathbf{H}$ \\
\hline $\begin{array}{cc}\mathbf{A} & \cdots \\
\mathbf{B} & \cdots \\
\mathbf{H} & \cdots \\
\mathbf{H} & \cdots\end{array}$ & $\begin{array}{c}\overline{-} \\
0 . \overline{124} \\
0.009 \\
-\end{array}$ & $\begin{array}{l}0.025 \\
0.014 \\
0.031 \\
0.011 \\
0.007\end{array}$ & $\begin{array}{c}0.83 \\
0.54 \\
\overline{0} \\
0.54\end{array}$ & $\begin{array}{c}0.25 \\
1.50 \\
= \\
=\end{array}$ \\
\hline
\end{tabular}

*Of 693 patient months in H, 46 were in hospital unit (state C).

(d) July 1971 to June 1973 (admission rate $2 \cdot 3$ per month)

\begin{tabular}{|c|c|c|c|c|}
\hline \multirow{2}{*}{$\begin{array}{c}\text { Transition } \\
\text { from } \\
\text { State }\end{array}$} & \multicolumn{2}{|c|}{$\begin{array}{l}\text { Probability per Patient } \\
\text { of Transition to State }\end{array}$} & \multicolumn{2}{|c|}{$\begin{array}{l}\text { Rate of Transition } \\
\text { (patients) to State }\end{array}$} \\
\hline & $\overline{\mathbf{A}}$ & $\mathbf{D}$ & $\mathbf{T}$ & $\mathbf{H}$ \\
\hline $\begin{array}{cc}\mathbf{A} & \ldots \\
\mathbf{B} & \cdots \\
\mathbf{T} & \ldots \\
\mathbf{H} & \cdots\end{array}$ & $\begin{array}{l}\overline{-} \\
0 \cdot \overline{114} \\
0.006\end{array}$ & $\begin{array}{l}0.051 \\
0.004 \\
0.028 \\
0.005 \\
0.005\end{array}$ & $\begin{array}{c}1.13 \\
0.54 \\
\overline{0.71}\end{array}$ & $\begin{array}{c}0.33 \\
1.67 \\
= \\
=\end{array}$ \\
\hline
\end{tabular}

*Of 890 patient months in H, 61 were in hospital unit (state C).

The model has been tested by using data for the earlier years of the Cardiff unit and comparing the predictions with the observed data for subsequent years. An example is given in Fig. 5, where the predicted values are shown as curves and the actual values as points. The predictions from July 1970 to June 1972 are based on data for the two-year period July 1968 to June 1970; the values for interstate transitions used in the calculation are shown in Table III. In this example the number of patients with functioning renal grafts is underestimated, mainly because transplant survival probabilities improved during the period.

As the model has only seven states and 16 interstate transitions, the errors of estimated transition rates or probabilities may be calculated simply. For example, in the period July 1968 to June 1970 there were 278 patient months in state A (the fourmonth admission unit) and 19 deaths from that state, giving a mean monthly probability of death from state $A$ of

$$
\mathrm{p}=\frac{19}{278} \pm \sqrt{\frac{1}{278} \cdot \frac{19}{278} \cdot \frac{259}{278}}
$$

During the same 24-month period 20 patients in state $A$ were given transplants, hence the mean monthly rate of transplantation from state $A$ was

$$
\frac{20}{24} \pm \frac{\sqrt{20}}{24}
$$

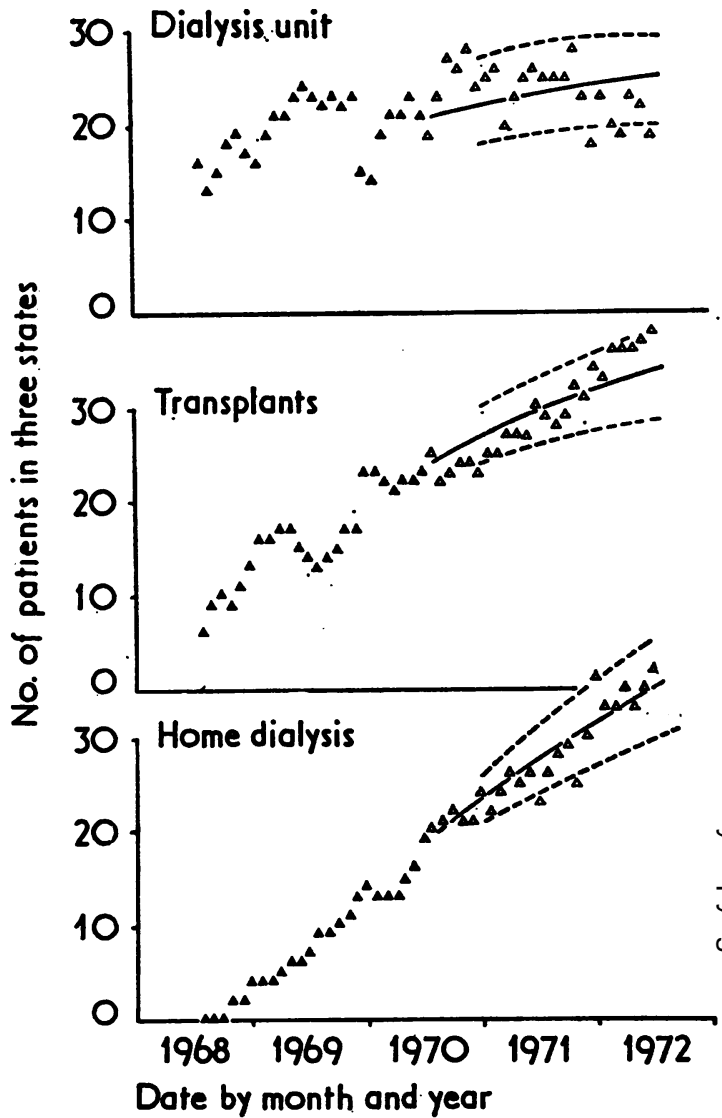

FIG. 5. Validity of the model. Data from July 1968 to June 1970 (A) provide for the prediction (continuous line), which is compared with the observed data from July 1970 to June $1972(\triangle)$.

\section{Forward Predictions}

Predictions for a five-year period beginning July 1973 have been calculated using the patient referrral rate (2.3 per month) and interstate transition rates of the most recent two years, July 1971 to June 1973 inclusive (Table III). The results are shown diagramatically in Fig. 6. The estimates for numbers in each state for June 1978 are $21 \pm 5$ on hospital dialysis, $86 \pm 8$ with functioning transplants, and $59 \pm 10$ on home dialysis (Table IV). The standard deviations are based on analysis of 100 repetitions of the simulation model. The recent rates of admission ( $2 \cdot 3$ patients per month) have been artificially low because the dialysis unit has not admitted for most of 1973 because of an outbreak of hepatitis. Several patients awaiting transplants have been maintained on peritoneal dialysis and for the purpose of forward projection they have been considered 
TABLE IV

PREDICTED NUMBERS IN DIALYSIS TRANSPLANTATION PROGRAMME IN JUNE 1978

\begin{tabular}{|c|c|c|c|c|c|}
\hline & \multicolumn{2}{|c|}{ Dialysis } & \multirow[b]{2}{*}{ Transplants } & \multirow[b]{2}{*}{ Died } & \multirow[b]{2}{*}{ Refused } \\
\hline & Hospital & Home & & & \\
\hline $\begin{array}{l}\text { Referral } 2 \cdot 3 \text { per month and interstate trans- } \\
\text { itions as in period July } 71 \text { to June } 73 \\
\end{array}$ & $21 \pm 5$ & $59 \pm 10$ & $86 \pm 8$ & $171 \pm 10$ & - \\
\hline 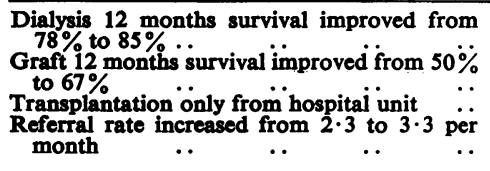 & $\begin{array}{l}24 \pm 5 \\
18 \pm 4 \\
22 \pm 5 \\
28 \pm 3\end{array}$ & $\begin{array}{l}69 \pm 10 \\
54 \pm 9 \\
84 \pm 9 \\
78 \pm 10\end{array}$ & $\begin{array}{r}88 \pm 8 \\
108 \pm 9 \\
65 \pm 7 \\
93 \pm 9\end{array}$ & $\begin{array}{l}157 \pm 8 \\
157 \pm 8 \\
166 \pm 8 \\
188 \pm 8\end{array}$ & $\begin{array}{c}- \\
- \\
12 \pm 8\end{array}$ \\
\hline
\end{tabular}

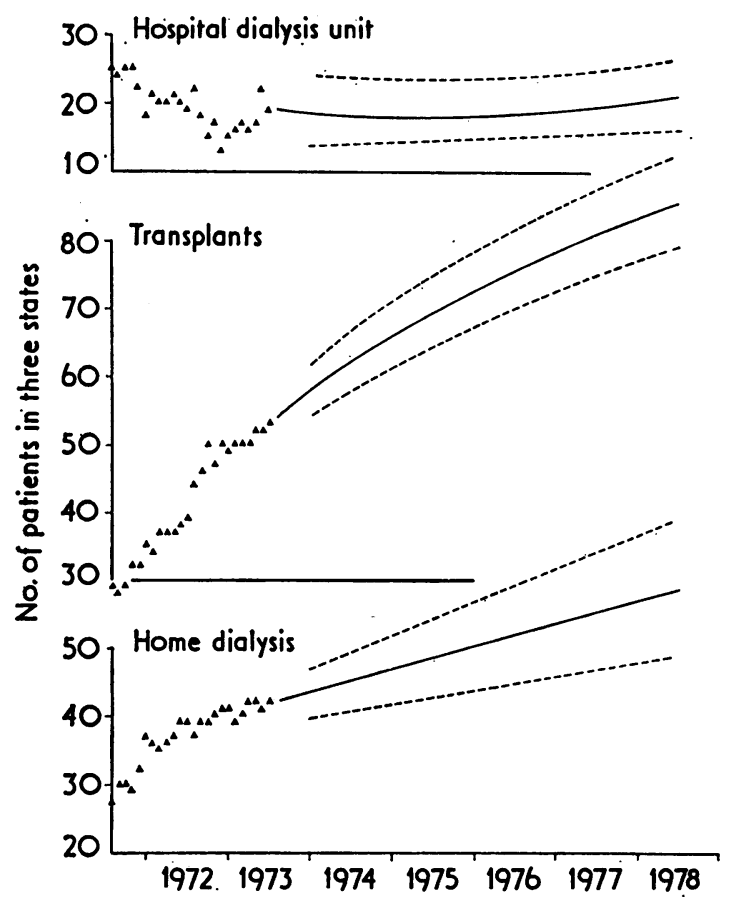

Date by month and year

FIG. 6. Predictions using the model. Data from July 1971 to June $1973(\Delta)$ provide for prediction (continuous line).

as admissions to the dialysis unit. Likewise the home training rate $(2.0$ patients per month) was accelerated in order to reduce the numbers in the hospital unit. The home training rate and the recent transplantation rate of 2.4 patients per month cannot be maintained unless the dialysis unit reopens and the admission rate increases again.

Several parameters may change during the coming years so the effects of some possible changes have been investigated. First, during the last two years (July 1971 to June 1973) the 12-month survival of hospital dialysis patients (both first admissions and readmissions and independent of home transfer and transplantation) was $78 \%$, while for the earlier period (July 1968 to June 1970) it had been $62 \%$. If that 12-month survival rate should improve further by one third to $85 \%$ accompanied by a pro-rata improvement in the survival rate for home dialysis patients, the model predicts that there will be 14 more patients alive in June 1978, the main change being in the number on home dialysis (69 \pm 10 instead of $59 \pm 10$, see Table IV).

The recent 12 months graft survival of patients newly transplanted was $50 \%$. If that survival should improve by one third to $67 \%$, with the same ratio of graft failure to patient deaths, the prediction for June 1978 is $108 \pm 9$ living transplants, accompanied by small reductions in the number on dialysis in hospital and at home (Table IV). Transplantation of patients successfully established on home dialysis increases the overall mortality, which is to be expected while the death rate following transplantation exceeds that of home dialysis patients. The third variation listed in Table IV gives the predicted number in five years if cadaver kidneys are offered to patients on hospital dialysis only.

Estimates of the incidence of uraemia and the requirements for maintenance haemodialysis by Branch et al. (1970 or 1971), Pendreigh et al. (1972), and McGeown (1972) indicate an admission rate for the South Wales population of two million, approximately twice that recorded. Therefore the model was run with higher referral rates, and the fourth variation listed in Table IV gives the estimated numbers in June 1978 with a referral rate of 3.3 per month. Approximately 12 patients will fail to obtain a place on the programme and with a higher referral rate the number refused becomes greater. The number refused may be reduced either by transplanting patients sooner after admission to hospital dialysis or by increasing the home training rate. 
A considerable increase in the transplantation rate would be possible if more cadaver kidneys were available. We have estimated that there were 100 potentially available cadaver kidneys in Wales in 1969 , more than five times the number that were used (Crosby, West, and Davies, 1971). The home training rate could be increased but the limiting factor at present is the delay in providing facilities for dialysis at home. A substantial increase in the number of patients on home dialysis would require a larger reserve allocation on the dialysis unit for emergency readmission and that in turn would tend to limit the admission rate to the unit.

\section{CONCLUSIONS}

A mathematical model of a dialysis transplantation programme reported by Farrow, Fisher, and Johnson (1971) was based on a 26-state Markov chain with constant probabilities for each interstate transition. The model described here is based on only seven states, and the interstate transitions are at constant rate or constant probability, depending on the constraints. Transitions to home dialysis are dependent on the home training rate within the unit and on the home conversion rate by the local authority, and are largely independent of the number of patients in the hospital dialysis unit. Similarly, the transplantation rate is largely dependent on the availability of cadaver kidneys. We have defined such transitions as occurring at constant average rates. By contrast, failure of transplants and deaths generally are more accurately described as occurring with constant average probabilities.

The forward projection for five years indicates that if there are no changes in current policies and results there will be about $166 \pm 13$ patients alive at the end of the period. About 86 will have renal transplants, 59 will be on home dialysis, and 21 will be on hospital dialysis. There is evidence to suggest that the dialysis/transplantation programme will not be capable of taking all patients referred if the referral rate is as high as in the first two years of the programme. Possible ways of increasing the capacity of the programme are increased home dialysis training and conversion rates, improved survival of transplants, or discontinuation of the present policy of offering transplants to patients successfully established on home dialysis.

Survival rates have increased markedly in recent years (Table III). However, without a substantial increase in the transplant survival rate and reduction in the time of home dialysis training and conversion the improvement in hospital dialysis survival merely means that more patients will fail to obtain places in the programme. In these circumstances the present policy of offering transplants to patients on home dialysis is hard to justify unless it can be shown conclusively that tissue typing significantly increases cadaver-donor graft survival.

\section{REFERENCES}

Branch, R. A., Clark, G. W., Cochrane, A. L., JONES, J. H. and SCARBOROUGH, H. (1971). Incidence of uraemia and requirements for maintenance haemodialysis. Brit. med. J., 1, 249.

- Coles, G. A., Crosby, D. L., Jones, J. H., Sussman, M., and ThomAs, W. J. C. (1970). Integrated regional haemodialysis and renal transplantation centre. Brit. med. J., 1, 291.

Crosby, D. L., West, R. R., and Davies, H. (1971). Availability of cadaveric kidneys for transplantation. Brit. med. J., 4, 401.

Farrow, S. C., Fisher, D. J. H., and Johnson, D. B. (1971). Statistical approach to planning an integrated haemodialysis/transplantation programme. Brit. med. J., 2, 671 .

McGeown, M. G. (1972). Chronic renal failure in Northern Ireland, 1968-70. Lancet, 1, 307.

Pendreigh, D. M., Heasman, M. A., Howitt, L. F., Kennedy, A. C., MacDougall, A. I., Macleod, M., Robson, J. S., and Stewart, W. K. (1972). Survey of chronic renal failure in Scotland. Lancet, $1,304$. 